\title{
Causing The Lecturers to Use Diagnostic Assessment to Find Out The Weaknesses of Students in Understanding Basic Reading in The Third Semester Students of Universitas Nahdlatul Ulama Blitar
}

\author{
Bagus Waluyo $^{(1)}$, Oikurema Purwati ${ }^{(2)}$, Slamet Setiawan ${ }^{(3)}$ \\ Universitas Negeri Surabaya, Indonesia \\ E-mail: (1)bagus.19003@mhs.unesa.ac.id, (2)pungki_unesa@yahoo.co.id, \\ (3)slametsetiawan@unesa.ac.id \\ Received: 3 March 2020; Revised: 20 April 2020; Accepted: 25 May 2020
}

\begin{abstract}
Abstrack
This research is based on the still problematic confusion of basic reading lecturers to determine the weakness of students in understanding basic reading so that there are still a number of students who are completely weak in the analysis of discourse content and have not been detected clearly. Diagnostic assessment to find out the weaknesses of students in understanding basic reading in the third semester students of of Universitas Nahdlatul Ulama Blitar is applied in this study. The research method used is a descriptive qualitative method. data collection technique in this study is using interview technique. In this study, the source of the data is the third semester Basic Reading Lecturer at Universitas Nahdlatul Ulama Blitar. The results show that the strong desire of the third semester basic reading lecturers at Universitas Nahdlatul Ulama Blitar to use Diagnostic assessment resulted from several factors, namely: a) easy to understand student's ability in reading analysis, and $b$ ) easy factor to know the weaknesses of students in understanding reading. From the description above it can be concluded that Diagnostic assessment is an appropriate facility for lecturers to find out the weaknesses of students who are the top priority in learning outcomes.
\end{abstract}

Key words: Diagnostic assessment, Basic reading

\section{Introduction}

The success or failure of an education can basically be seen from changes in attitudes and behavior or from the achievements of learning outcomes achieved by students who have received the learning process. But not all teaching and learning activities can get optimal results as desired by the teacher in achieving the goals set. What has been achieved by students doing learning activities is often called learning outcomes. About what has been achieved by students after learning activities, there is also a mention with the term learning outcomes stated by (Sudjana, 1991). The achievement of student learning outcomes refers to aspects of cognitive, effective and psychomotor. Therefore the three aspects above must be as indicators of learning outcomes. That is, learning outcomes must include aspects of cognitive, effective and psychomotor. According to Sudjana, the three aspects above do not stand alone, but an inseparable unity, even forming a hierarchical relationship.

Therefore here learning outcomes greatly influence in improving the quality of learning for students who want to develop insight, or develop students' skills through evaluations - evaluations will be realized student learning outcomes.

The ability to achieve or for learning outcomes is a peak learning process. At this stage students prove learning success. Students show 
that they have been able to solve learning tasks or transfer learning outcomes. from daily experience at school, it is known that there are some students who are unable to perform well. The ability to excel is affected by the processes of acceptance, activation of the processors and experience. If the process is not good, then students can underachieve or can also fail to achieve. Learning outcomes are abilities obtained by children after going through learning activities (Abdurrahman, 1999). Learning itself is a process of someone who is trying to obtain a form of behavior change that is relatively sedentary. In addition to knowing the learning outcomes, in accordance with the learning objectives, required assessment in accordance with the conditions of students so that the weaknesses and strengths of students can be detected well. Lecturers need to determine the right test approach to measure these problems. Diagnostic assessment is a good measuring tool to determine the weaknesses and strengths of students, especially in learning basic reading. According to (Fox, 2017) Diagnostic assessment help the lecturers to know the weaknesses and strengths of students in understanding certain subject matter accurately and can also help students to increase awareness in understanding the mistakes themselves in the learning process. (Goodman, 1967)) defines reading as a process which involves using available language cues that are selected from perceptual input on the basis of reader's predictions. As the information is processed, tentative decisions about meaning are confirmed, rejected, or refined as the reading progresses. Graphic information in the topdown models is used only to support or reject hypotheses about meaning. More simply stated, reading is a psycholinguistic guessing game. It involved an interaction between thought and language. Efficient reading does not result from precise perception and identification of all elements, but from skill in selecting the fewest, most productive cues necessary to produce guesses which are right in the first time. The ability to anticipate that which has not been seen, of course, is vital in reading. Just as the ability to anticipate what has not yet been heard is vital in listening.

This study aims to determine the cause of the lecturers using Diagnostic assessment to find out the weaknesses of students in understanding basic reading in the third semester students of Universitas Nahdlatul Ulama Blitar, so the questions are formulated as follows: Does
Diagnostic assessment make it easier for lecturers to find out the weaknesses and strengths of the third semester students in understanding Basic Reading material at the University of Nahdlatul Ulama Blitar? To help the research smoothly, basic reading lecturers, at the same level in research, were subjected to take data in the interview process about the experience of teaching basic reading lessons in the third semester at different times.

\section{Material and Methods}

The method used in this research is descriptive method with a qualitative approach. (Denzin, 2005) Qualitative research is a type of social science research that collects and works with nonnumerical data and that seeks to interpret meaning from these data that help us understand social life through the study of targeted populations or places. And also qualitative model is ill suited to " examining the complex and dynamic contexts of public education in its many forms, sites, and variations, especially considering the...subtle social difference produced by gender, race, ethnicity, linguistic status, or class.

Data sources in research are subjects from which data can be obtained. If the researcher uses a questionnaire or interview in gathering data, then the source of the data is called respondent people who respond or answer the questions of researchers, both written and oral questions). When using observation, the source of data can be in the form of objects, movements or processes. If the researcher uses documentation, then the document or notes is the source of the data. So in this study, the source of the data was Basic Reading Lecturers at the University of Nahdlatul Ulama Blitar.

The most important part of the research process is the research data. Therefore, the core of a study is the collection of data or information. then the data is processed or analyzed and finally the results of the analysis are translated or interpreted as research conclusions. So in this study the data used is taken from the learning process of Basic Reading subjects by interviewing lecturers after the learning process.

Data collection techniques, which are considered relevant, are direct communication techniques when interviewing lecturers. (Gubrium, 2001) An interview is a conversation for gathering information. A research interview involves an interviewer, who coordinates the process of the conversation and asks questions, and an interviewee, who responds to those questions Interviews can 
be undertaken face-to-face or by telephone. The Digital world is also springing up as a tool for interviewing people. Interviews can be arranged differently depending on the needs and information being addressed. They can be categorized into three types: organized interviews: in an organized interview, the interviewer asks a set of specification, preordained questions about specific topics in a specific order. Respondents need to choose their answers from a list of options. Some questions may be clarified by the interviewer. Structured Interviews are typically used in surveys (see our "Survey Research Methods" Tip Sheet for more information). Semi-structured interviews: In a semi-structured interview, the interviewer uses a set of predetermined questions and the respondents answer in their own words. Some interviewers use a topic guide that serves as a checklist to ensure that all respondents provide information on the same topics. The interviewer can probe areas.

Based on the respondent's answers or ask supplementary questions for clarification. Semistructured interviews are useful when there is a need to collect in-depth information in a systematic manner from a number of respondents or interviewees (e.g., teachers, community leaders). Unstructured interviews: In an unorganized interview, the interviewer does not have any specific guidelines, limitations, fixed questions or list of choices. The interviewer asks a variety of broad questions to involve the participant in an open, casual and natural conversation. The interviewer also investigates further questions and/or explores discrepancies to gather further in-depth information on the subject. Unorganized interviews are particularly valuable to get stories behind the memories of the respondents or when there is little information about the subject. Direct Observation, Direct Communication Technique is a way to collect data that requires a researcher to make direct contact orally or face to face (face to face) with data sources, both in actual situations and in situations that are intentionally made for these purposes. The source of the data in this study is a Lecturer at the University of Nahdlatul Ulama Blitar. the document used in this study was the result of an interview with a Basic Reading teaching lecturers. In this study, researchers used Structured interviews as a reference model for data collection when conducting interviews with lecturers supporting basic reading subjects. To draw conclusions from the data obtained, data processing is required. The steps that researchers will take are; 1) Collecting data through interviews ,. 2) Analyzing the data that has been obtained. 3) Conduct descriptive analysis combined with theories. And 4) conclusion.

\section{Results and Discussion}

The following is an overview of the teaching process treatments that use Diagnostic assessment to the lecturers who teach third semester Basic Reading at university of Nahdlatul Ulama Blitar at different times and examples of the Diagnostic assessment tool.

Table 1. Diagnostic approach

\begin{tabular}{|l|l|}
\hline Approach & How does it work ? \\
\hline Learning & $\begin{array}{l}\text { During the course, students keep a } \\
\text { previous record of their jobs. After } \\
\text { finishing the course mission, they } \\
\text { respond to the question. Teacher } \\
\text { gathers the learning log and review } \\
\text { responses in addition to the finalized } \\
\text { assignment. } \\
\text { Administer the same or similar test at } \\
\text { interval during a course. } \\
\text { Students take the same exam at the } \\
\text { beginning, middle and end of the } \\
\text { program to record changes over time. } \\
\text { Teachers should allow use of the } \\
\text { internet study, the textbook, and so } \\
\text { on, which are relevant to the specific } \\
\text { course they are teaching. At inter- } \\
\text { vals, the teacher prescribes the exam } \\
\text { and keeps track of how each student } \\
\text { does it. Student meet one-on-one or } \\
\text { in small groups with the teacher } \\
\text { Teachers provide instant feedback to } \\
\text { support student learning and promote } \\
\text { students to think about their work in } \\
\text { other and more complex ways. }\end{array}$ \\
\hline
\end{tabular}

Table 2. A sample diagnostic assessment tool

\begin{tabular}{|l|l|}
\hline Criteria & $\begin{array}{l}\text { Possible Language } \\
\text { Support }\end{array}$ \\
\hline Main ideas & \\
Organization of ideas & \\
Stated detail question & \\
Unstated detail question & \\
Pronoun referents & \\
Implied detail question & \\
Transition & \\
Definition or synonym & \\
\hline
\end{tabular}

Based on interviews with Basic Reading lecturers, there are several factors, that concern to Basic Reading lecturers, prefer to use diagnostic assessment, as follows: 1) Lecturers can easily find out the abilities and weaknesses of students, especially in understanding Basic Reading sub- 
ject, 2) Lecturers can find out the development of students' abilities in the learning process easily, and 3) Lecturers easily design questions in accordance with learning objectives integrated with the internet or books. Thus Diagnostic assessment is very helpful for lecturers to decide on policies in teaching in class about additional material or material sustainability.

So the results of interviews with lecturers of basic reading courses after using Diagnostic assessment in the teaching process illustrates that Diagnostic assessment really helps them in the learning process in class because the test can help lecturers to know the strengths and weaknesses of students during the learning process and can also help them in determining repetition or continuation of integrated material from the internet or books so that learning outcomes in class can match the target of advanced learning. According to (Hadi \& Ismara, 2015) Diagnostic assessment is very good to know and measure the quality of the system marked aspects of performance, design, and adaptability. (Sadono \& Rahayu, 2012) Remedial determination through diagnostic tests can help analyze students' weaknesses and student achievement grades according to the target of study. And according to (Fox J. , 2009) Diagnostic assessment has a very good role in supporting the learning process of adults in the EAP program because it can help knowing the development of students in following the learning process so that the results of learning objectives can be achieved.

\section{Conclusion}

The application of Diagnostic assessment in the learning process in the classroom really helps the lecturer to know the weaknesses and strengths of students in studying learning outcomes, especially basic reading subjects so that the expected results can be achieved optimally and also the lecturer can determine the direction of teaching policy in giving reviews or continuing teaching according to the role of teaching, they can even be more attentive to certain learning cases to provide solutions that can improve strategies for achievement in learning. For lecturers, especially teachers of basic reading courses are expected to apply Diagnostic assessment in determining learning outcomes because it is very valid to determine the weaknesses and strengths of students in understanding learning outcomes in class.

\section{References}

Abdurrahman, M. (1999). Pendidikan Bagi Anak Berkesulitan Belajar. Jakarta: Rineka Cipta.

Denzin, N. K. (2005). Qualitative Research. California: Sage Publication Press.

Fox, J. (2009). Moderating top-down policy impact and supporting EAP curricular renewal: Exploring the potential of diagnostic assessment. Jounal of Academic purposes, 42.

Fox, J. (2017). Assessment in the Language Classroom. London: PALGRAVE.

Goodman, K. S. (1967). Reading : A Psycholinguistic Guessing Game. Journal of The Reading Specialist, 12.

Gubrium, J. (2001). Handbook of interview research: context and Method. California: SAGE.

Hadi, S., \& Ismara, I. (2015). PENGEMBANGAN SISTEM TES DIAGNOSTIK KESULITAN BELAJAR KOMPETENSI DASAR KEJURUAN SISWA SMK 1. Jurnal Penelitian dan Evaluasi Pendidikan, 9.

Sadono, \& Rahayu, W. (2012). TES DIAGNOSTIK UNTUK PROGRAM REMEDIAL PADA PEMBELAJARAN MATEMATIKA . Jurnal Evaluasi Pendidikan, 12.

Sudjana, N. (1991). Teori- Teori Belajar Untuk Pengajaran. Bandung: Rineka Cipta. 